\title{
USEING ALGAL ORGANIC FERTILIZERS
}

\author{
Élica Amara Cecilia Guedes ${ }^{1}$, Gaus Silvestre de Andrade Lima², Laurício Endres²* \\ ${ }^{1}$ Instituto de Ciências Biológicas e da Saúde, Universidade Federal de Alagoas. Praça Afrânio Jorge, S/N, 57010-020, \\ Maceió, AL. \\ ${ }^{2}$ Centro de Ciências Agrárias, Universidade Federal de Alagoas. BR 104 - Norte, Km 97, Cidade Universitária CEP 57072- \\ 970 ,Maceió, AL. \\ 'Autor para correspondência: Laurício Endres, endres@pq.cnpq.br.
}

\begin{abstract}
Algae have been explored as inorganic nutrient sources, human and animal food and biochemical products. Several beaches in the northeastern state of Alagoas, Brazil, frequently experience large amounts of algal drifts, representing a huge amount of biomass that could be used as an organic fertilizer for coastal farmers. The purpose of this study was to observe the growth and development of lettuce grown using algal with organic fertilizers. The lettuce was grown in the following conditions: controlled, soil neither algal powder nor cattle manure, soil plus 5\% of algal powder, and soil plus $5 \%$ of cattle manure. The lettuce plantlets were transferred to a substrate and harvested with after 60 days. The fresh and dry mass, shoot and root length of the lettuce plants, and the mineral nutrient content of the algae fertilizer were evaluated as parameters Algae fertilizers have low levels of phosphorus and but have suitable levels of other mineral nutrients when compared to other organic fertilizers. Algal fertilizers induced a similar growth response in lettuce plants compared to cattle manure. Overall, this data lets us conclude that algal drifts, with the addition of phosphorus and potassium, might be a good resource as an organic fertilizer.
\end{abstract}

Index terms: Lactuca sativa L., organic fertilizer, algae, manure

\section{UTILIZAÇÃO DE MATÉRIA ORGÂNICA FEITA DE ALGAS}

RESUMO: As algas têm sido exploradas como fonte de nutrientes inorgânicos, alimentação humana e animal e para a extração de produtos bioquímicos. Muitas praias do Nordeste Brasileiras possuem grande quantidade de algas arribadas, representando uma fonte de biomassa que pode ser usada como adubo orgânico para agricultores do litoral. $\mathrm{O}$ objetivo desse estudo foi observar o crescimento e desenvolvimento de alface utilizando adubação orgânica feita de algas arribadas. No experimento, foram empregados os seguintes tratamentos: controle (sem adubação); solo com $5 \%$ de farelo de algas; e solo com $5 \%$ de esterco bovino. Em seguida, foram transplantadas plântulas de alface e colhidas após 60 dias. Os parâmetros avaliados foram massa fresca e seca, crescimento da parte-aérea e raiz das plantas de alface. Ainda foi avaliado o conteúdo de elementos minerais da farinha de algas. A farinha de algas apresenta baixos níveis de fósforo e potássio, no entanto níveis satisfatórios de outros nutrientes minerais quando comparado com outros adubos orgânicos. Esse adubo induziu respostas similares de crescimento de plantas de alface quando comparado com esterco bovino. Podemos concluir que a farinha de algas pode ser uma boa fonte de adubo orgânico, principalmente quando adicionado fósforo e potássio.

Termos para indexação: Lactuca sativa L., adubação orgânica, algas, esterco

\section{INTRODUCTION}

Alga represents a cosmopolitan group of plantlike Protists, which grow on all type of soil surfaces, even on permanent ice and snow-covered soils. The major concentrations of algae are in the ocean and continental waters, which cover over $70 \%$ of the earth (Round, 1980).
Since iodine and bromide were considered to be algae constitute, lodine and bromide have been exploited as an inorganic elements sources and have been largely used as human and animal food and also as biochemical product extractions (Levring et al., 1969). Algae have also been found to be amino acid (Pellegrini, 1969) and antibiotic (Pinheiro-Vieira \& Caland-Noronha, 1971; and Fenical \& McConnel, 1976) 
sources, which make them useful for the pharmaceutical and cosmetic industries, and for animal and human consumption (Mabeau \& Brault, 1989).

The algae have been used as fertilizers since ancient times. For example, Egyptian algae, from continental waters, were used as a fertilizer in flooded areas of Nile River (Rio, 1970). The chemical composition of algae is possible detect reasonable amounts of phosphorus, potassium (Aitken \& Senn, 1963; and Yokoyama \& Guimarães, 1975), magnesium, manganese, zinc and boron (Booth, 1953; Yamamoto et al., 1979; and Pelegrini et al., 1987) which are important mineral elements fo benefiting plant nutrition.

On some shores, algae drifts accumulate in large amounts. These are drifted up on the beach with the reflux of the tide toward the sea, driven by the wind and sea currents. Farmers, who live near the coast, historically have collected drifted algae to use as humus (Rio, 1970). Humus was formed of decaying algal matter, which improves the quality of the soil allowing improving aeration and humidity (Rio, 1970).

Several beches in the northeastern state of Alagoas, Brazil, frequently covered with large quantities of drifted algae. Guedes \& Moura (1996) studied the biomass and the mineral composition of these algae and suggested that this material should be used as raw material for humus production and for animal food improvement. The objective of this study was to observe the growth and development of lettuce using algal organic fertilizers.

\section{MATERIAL AND METHODS}

The algae were collected from drifts from the Ponta

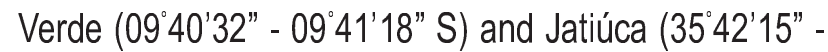
$09^{\circ} 43^{\prime} 05^{\prime \prime} \mathrm{W}$ ) beaches located in Maceió, the capital of

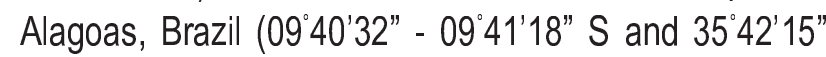
- $09^{\circ} 43^{\prime} 05^{\prime \prime}$ W), during the period of February to March, 2000 . Both beaches are approximately $6 \mathrm{~km}$ long and $5 \mathrm{~m}$ wide covered with drifted algae. Algae is a mixture of the phylum Chlorophyta, Phaeophyta and Rhodophyta. The algae were collected from ten randomized places, and dried in the sun for 15 days. The dried algae were ground and the powder was separated into two portions, one for chemical analysis (Kiehl, 1985; and Orlando Filho, 1983) and the other one for organic fertilizer experiments. The chemical analyses were made by Central Analítica Ltda, Maceió, Brazil.
Fifteen-day-old lettuce plantlets (Lactuca sativa L.) CV "saia veia" germinated in sand substrate and then were transferred to polyethylene bags with $4 \mathrm{dm}^{-3}$ $(4 \mathrm{~L})$ capacity. The following experiments were done: (1) control, soil without either algal powder or cattle manure, (2) soil with $5 \%(\mathrm{wt} / \mathrm{wt}$, ) of algal powder, and (3) soil with $5 \%$ (wt/wt) of cattle manure. The amount of organic fertilizer was calculated in agreement with Murayama (1973), who recommended $8 \mathrm{~kg}$ of cattle manure for each square meter of soil. After fortyfive days, the plants were harvested for quantitative analyses. The fresh and dry mass, the total number of leaves per plant, and the shoot and root lengths of the plants were all evaluated. Some samples were also collected for nutrient determination (Kiehl, 1985). The plants were dried at $70^{\circ} \mathrm{C}$ for three days to get the dry mass measurement. In the cultivation experiments, each treatment was repeated 60 times (bags). The analysis of variance (ANOVA) and the more significant difference were tested using the Tukey studentized range test at $P<0.05$ level.

\section{RESULTS AND DISCUSSION}

The mineral elements were compared to different organic fertilizers (Table 1). The nitrogen concentration of drifted algae powder was lower than in the other organic fertilizer (Table 1), and contained limited levels of phosphorus and potassium. According to Levring et al. (1969), mixing algae with superphosphate makes a good fertilizer for improving sandy soils.

The algal powder also had suitable levels of calcium and magnesium in compararison to to other organic fertilizers. The algae contain calcareous algae that contains substantial amount of calcium carbonate and magnesium carbonate (Dias, 2000). Thus, the continental platform of the Northeast of Brazil has frequent occurrences of calcareous algae (Kempf, 1970; and Coutinho, 1992), which may explain the large amounts of nutrients in the collected algae analyzed in this study. The level of sodium and chlorine was also high in these algal samples, which can be explained.

The plants fertilized with either manure or algae had significantly higher fresh mass than the controlled plants (Figure 1A). However, there was no difference in between the treatments when compared to the plants dry mass (Figure 1B). 
TABLE 1 - Mineral nutrients of drifted algae and other organic fertilizers commonly used in agriculture as organic fertilizers.

\begin{tabular}{|c|c|c|c|c|c|}
\hline \multirow[b]{2}{*}{ Nutrients (\%) } & \multicolumn{5}{|c|}{ Organic Fertilizer } \\
\hline & Swine manure ${ }^{1}$ & Poultry manure ${ }^{2}$ & Cattle manure $^{3}$ & Vermin compost ${ }^{3}$ & Algal powder \\
\hline Nitrogen & 2,37 & 1,44 & 2,7 & 2,4 & 0,806 \\
\hline Phosphorus & 1,48 & 2,42 & 1,2 & 1,3 & 0,041 \\
\hline Potassium & 0,32 & 2,11 & 1,7 & 0,5 & 0,056 \\
\hline Calcium & 3,27 & 8,76 & 1,7 & 1,5 & 2,039 \\
\hline Iron & 0,381 & - & 0,8 & 2,8 & 0,205 \\
\hline Magnesium & 0,378 & 0,66 & 0,8 & 0,6 & 0,378 \\
\hline Zinc & - & 0,028 & 0,011 & 0,020 & 0,001 \\
\hline Copper & 0,018 & - & 0,005 & 0,011 & 0,0004 \\
\hline Manganese & 0,028 & - & 0,034 & 0,065 & 0,003 \\
\hline Sodium & & - & & & 1,079 \\
\hline Chlorine & & - & & & 3,605 \\
\hline
\end{tabular}

${ }^{1}$ Wang \& Yang (2003); ${ }^{2}$ Adegbidia et al (2003); ${ }^{3}$ Yagi et al (2003).
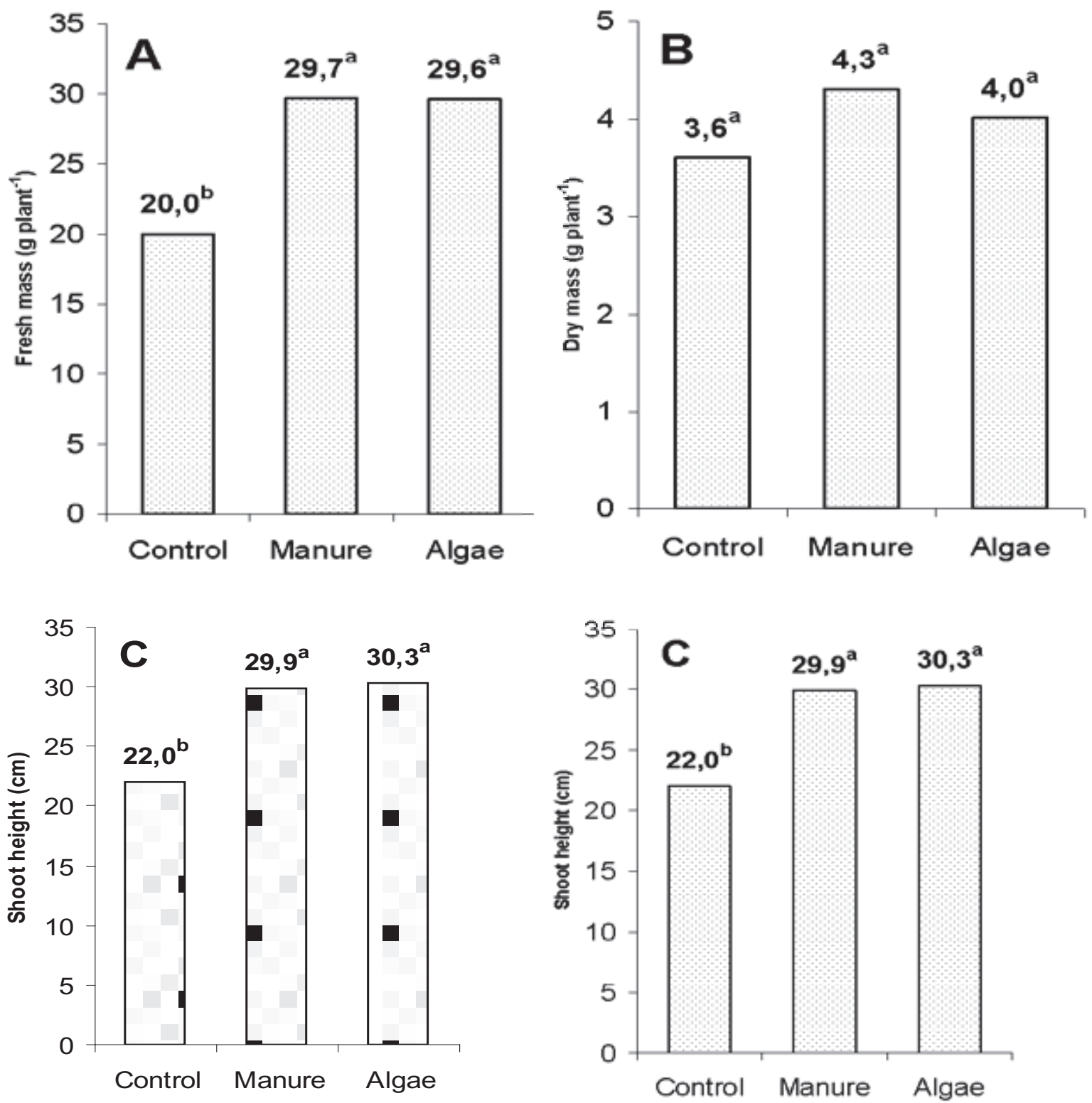

FIGURE 1. Fresh (A) dry (B) mass, shoot height (C), and root length of lettuce plants (Lactuca sativa L.), cv "saia veia" cultivated in soil (control) or fertilized with $5 \%$ of manure or $5 \%$ of algal powder after 60 days of cultivation. 
The greater fresh mass of the organic fertilized plants was associated to the shoot growth (Figure 1C). The plants grown with either manure or algae also exhibited a darked green. No significant difference was found in the increase of the root growth (Figure 1D) and the number of leaves per plant.

These results showed that algal powder is a suitable organic fertilizer for cultivating lettuce, equivalent to cattle manure. Because of its high nutrient levels, some authors suggest that algal powder can even be a better organic fertilizer than manure (Levring et al., 1969). In this study, the collected algae appear to be a suitable source of nitrogen. The high levels of chlorine and sodium may be harmful to crops that cannot tolerate saline stress. This effect can be diminished by higher levels of irrigations or by a higher rainfall level, characteristics found in the Zona da Mata region (Brazilian coastal rainforest region) where rainfall is abundant, facilitating the salt dilution.

Another benefit of the algae as a fertilizer is that they can also change the physical proprieties of the soil. According to Wilkie \& Mulbry (2002), this organic fertilizer improves the stability of the soil clusters, minimizes soil erosion and maximizes soil aeration, maximizes the movement of water and its retention, and minimizes the use of fertilizers. Millions of tons of fresh algae rot on Brazilian beaches, instead, this resource can become an excellent organic fertilizer for coastal agriculture soils.

\section{CONCLUSIONS}

Even though algae fertilizer have low levels of phosphorus and potassium, but suitable levels of other mineral nutrients when compared to other organic fertilizers, they induced similar growth response in lettuce plants and cattle manure. These conclusions let us conclude that algal drifts, with the addition of phosphorus and potassium, shows doubt be a good resource as an organic fertilizer.

\section{BIBLIOGRAPHICAL REFERENCES}

AITKEN, J. B.; SENN, T. L. Seaweed products as a fertilizer and soil conditioner for horticultural crops. Botanica Marina, v.8, p.144-148, 1963.

BOOTH, E. Seaweed as a fertilizer. Organic Gardening, v.21, p.14-17, 1953.
COUTINHO, P. N. Sedimentos carbonáticos da plataforma continental brasileira. Revista de Geologia, v.6, p.65-73, 1992.

DIAS, G. T. M. Marine bioclasts: calcareous algae. Revista Brasileira de Geofísica, v.18, p.307-318, 2000.

FENICAL, W.; McCONNEL, O. J. Simple antibiotics from red seaweed Dasya oedicellata var. stanfordiana. Phytochemistry, v.15, p.435-436, 1976.

GUEDES, E. A. C.; MOURA, A. N. Estudo da biomassa e composição mineral de algas arribadas em praias do litoral norte de Alagoas. Boletim Estudos de Ciências do Mar, v.9, p.19-30, 1996.

KEMPT, M. Notes on the benthic bionomy of the N-NE Brazilian Shelf. Marine Biology, v.5, p.213-224, 1970.

KIEHL, E. J. Fertilizantes orgânicos. Piracicaba: Agronômica Ceres Ltda, 1985. 492p.

LEVRING, T.; HOPE, A.; SCHIMD, O. J. Marine algae, a survey of research utilization. Hamburg: Gram de Grynter \& Co., 1969. 421p.

MABEAU, S.; BRAULT, T. D. Utilisation des algues en alimentation humaine: des debouchés prometteurs. Equinoxe, v.29, p. 4-8, 1989.

MURAYAMA, S. Horticultura. 2.ed. Campinas: Instituto Campineiro de Ensino Agrícola. 1973. 321p.

ORLANDO FILHO, J. Nutrição e adubação de canade-açúcar no Brasil. Piracicaba: IAA/Planalsucar, 1983. 369p.

PELEGRINI, M.; PELLEGRINE, L.; CHABOT, R.; PERCHEHAIS, S.; YVIN, J. C. Effects of a liquid extract derived from Ascolhyllum nodosum on the ultrastructure of Vitis vinifera leaf tissue. Botanica Marina, v.30, p.437-446, 1987.

PELLEGRINI, M. Contribuition à l'étude chemique des algues mediterranéenes. Composition en acids aminés de Falkenbergia rufolanosa ( Harvey) Schmitz et d'Adparagopsis armata Harvey. Botanica Marina, v.12, p.179-184, 1969. 
PINHEIRO-VIEIRA, F.; CALAND-NORONHA, M. C. WILKIE, A. C.; MULBRY, W. W. Recovery of dairy Atividade antibiótica de algumas algas marinhas do manure nutrients by benthic freshwater algae, Estado Ceará. Arquivos Ciência Marinha, v.11, p.91- Bioresource Technology, v.84, p.81-91, 2002. 93, 1971.

YAMAMOTO, Т.; OTSUKA, Y.; OKASAKI, M.; RIO, E. C. Contribuição ao estudo do aproveitamento OKAMOTO, K. The distribution of chemical elements das algas marinhas como adubo. Tecnologia, v.2, p.35-40, 1970.

in algae. In: HOPPE, H. A.; LEVRING, T.; TANAKA,Y. (Ed.) Marine algae in pharmaceutical science. Berlin: Walter De Grunter, 1979. p.569-607.

ROUND, F. E. Biologia das algas. Rio de Janeiro: Guanabara Dois, 1980. 263p.

YOKOYAMA, M. Y.; GUIMARÃES, O. Determinação dos teores de $\mathrm{Na}, \mathrm{K}, \mathrm{Pe}$ proteínas em algumas algas marinhas. Acta Biológica Paranaense, v.4, p.19-24, 1975. 